GREAT EGRET (formerly COMMON EGRET): The first record of this species for Saskatoon was an individual observed at Pike Lake Provincial Park on June 10-12, 1974. It was first seen by Mary Houston and later observed by Jim Hogg, John Shadick, Mr. and Mrs. Hoyte and the writer.

TRUMPETER SWAN: One identified by call on Aug. 22, 1971, by G. Galloway and other members of a Saskatoon N.H.S. canoe trip along the South Saskatchewan River near Saskatoon was the first definite local record. Other possible sightings were made on Aug. 10 and 29, 1971 .

GREATER SCAUP: A male was observed at Blackstrap Lake at close range on Nov. 12, 1972. On April 26, 1973, another male bird was observed on a dugout near Vanscoy. These observations, the first for Saskatoon, were both made by the writer.

OLDSQUAW: The first record of this species occurred on Nov. 15, 1970, when a flock of 27 birds was observed at Blackstrap Lake and a single bird was sighted on the river in the city. These sightings were made by J. B. Gollop, Maureen DuWors, Stuart Houston, John and Stan Shadick. On Nov. 7, 1974, a single bird was again sighted on Blackstrap Lake by J. B. Gollop.

HARLEQUIN DUCK: A male was sighted at the weir on the river in the city between June 22 and 26, 1973. This was the first Saskatoon record. Further details in the June, 1974, Blue Jay.

BROAD-WINGED HAWK: The first breeding record of this species for Saskatoon was a nesting pair found near Pike Lake by Wayne Harris on May 25, 1974. Three young were banded at this nest by Stuart Houston on July 10.

GYRFALCON: Definite sightings made by various members of the Saskatoon N.H.S. were as follows: Feb. 26, 1970; Oct. 23, Nov. 24, Dec. 26 and 27, (dark phase), and Dec. 29, 1971 (white phase); Jan. 9 and 10, Oct. 7 and 27, and Dec. 26, 1973, and Oct. 5, 1974. The only previous record was on April

\section{6, 1967}

YELLOW RAIL: Observations based on calls were made at marshes south of the city on Aug. 2, 1970, by R. E. Gehlert and on June 5, 1973, by Wayne Harris.

WHIMBREL: The first definite sighting of this species was a group of three birds observed by Wayne Harris near Dundurn on June 6, 1973.

(WESTERN SANDPIPER): A probable record of this species was observed by Alan Smith near Vanscoy on July 25 1974. It was observed for 20 minutes using a $60 \mathrm{X}$ scope and the following field marks were noted: rusty cap anc crown, black legs, long bill witl "droop" at end, breast markings gre instead of brown. Unfortunately, as second observer was not available anc a photograph could not be taken, thi record cannot be considered confir med. There is no previous definit record for Saskatchewan.

HUDSONIAN GODWIT: Unusually larg concentrations of this species wer reported on Porter Lake, $11 \mathrm{mi}$. ENI of Saskatoon. Highest estimates wer 1970: 59; 1971: $847+212$ uniden tified godwits; 1972: $89+$ severa hundred unidentified godwits; 1973 1,150 . However in 1974 only fou birds were seen all summer. Furthe details in the Sept., 1971, and Junc 1974 issues of Blue Jay.

RUFF: The first record of thi European straggler was made on $\mathrm{Ma}$ 9, 16 and 19, 1970, when a single bir was observed at a slough near the air port. See the March, 1971, Blue Jay fo further details.

MEW GULL: The first record of th species was observed at the weir in th city by Wayne Harris on Oct. 4, 197 : The bird was described as a white headed gull with a solid yellow bi with no mark of any kind.

LITTLE GULL: Saskatoon's first recor was an immature bird studied for 1 minutes at Blackstrap Lake on Oct. 1973, by J. B. Gollop.

CASPIAN TERN: Four birds

Blackstrap on June 26, 1970, (J. I Gollop) and seven birds there on Ju 18, 1970, (J. A. Wedgwood) were th 


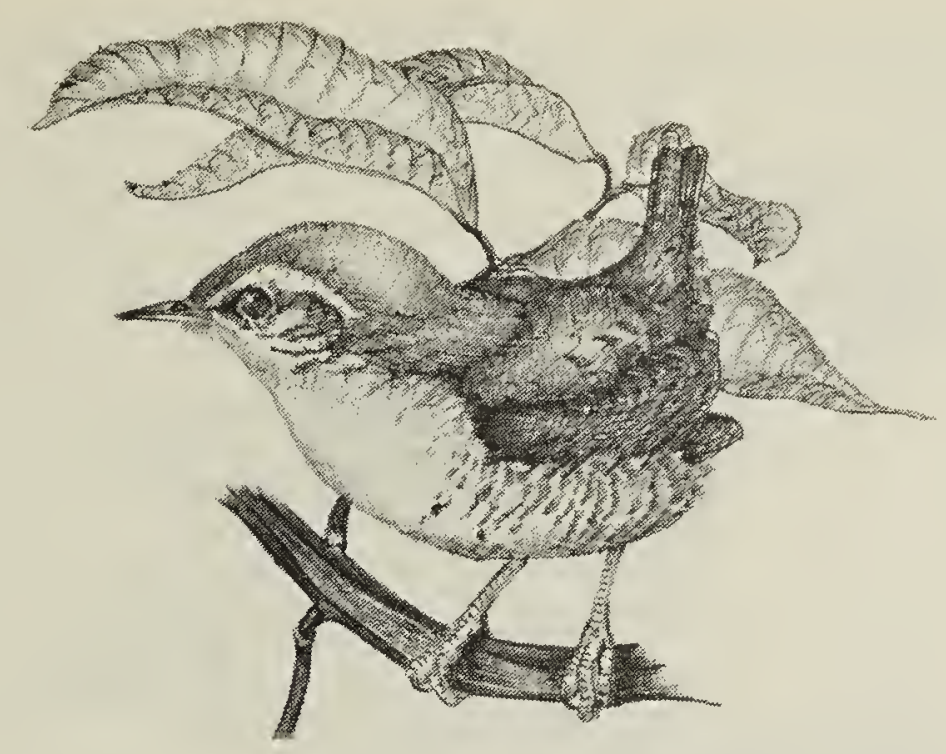

Winter Wren

C. J. Trefry

irst records for the district. An immature was noted at Hague Ferry just horth of the district on Sept. 9, 1973, y Stuart Houston.

BAND-TAILED PIGEON: A single bird bserved in the city on Sept. 30, 1970, y Mrs. S. Aldous was the first local record.

\section{LACK-BACKED THREE-TOED WOOD-} PECKER: An individual observed by Alan Smith in the city on Nov. 20, 1971, was the third record for the Histrict.

\section{NORTHERN THREE-TOED WOOD-} PECKER: Saskatoon's first record was a emale observed by Lynn Oliphant in he city on Oct. 11, 1974.

ALDER FLYCATCHER: The first nest of his species was found near Ardath on luly 31, 1971, by Wayne Harris, J. A. Wedgwood, J. B. Gollop and the vriter.

ROUGH-WINGED SWALLOW: A pair lesting at Eagle Creek near Asquith on May 27, 1973, was the first record of his species. A pair nested again at the ame location in 1974. (J. B. Gollop, Stan Shadick)

CLARKE'S NUTCRACKER: An immature bird was observed Nov. 18-23, 1972 , outh of Saskatoon. This was the first ecord for Saskatoon. (See Blue Jay, ept., 1973)

PED-BREASTED NUTHATCH: A nesting air found by the writer in a city park n May, 1974, was the first breeding ecord.
WINTER WREN: One observed in the city on Oct. 22 and 24, 1972, by $\mathrm{Mr}$. and Mrs. J. A. Wedgwood was Saskatoon's second record. Another was observed just north of the city on Oct. 2, 1973, by Wayne Harris.

ROCK WREN: The first record of this species was observed in September, 1974, south of Floral by W. J. Maher.

BENDIRE'S THRASHER: On May 27, 1972, the first Canadian sight record of this species was observed for about 15 minutes with binoculars and spotting scope by Dr. and Mrs. J. B. Gollop west of Hanley. The bird was a brown colour (not pale or reddish), had a straw-coloured eye, streaked front and no wingbars.

VARIED THRUSH: Single birds were observed in the city on Sept. 4 and 12, 1970, and on Oct. 4, 1971, by J. D. Hogg, Mrs. S. Aldous and Mrs. Pat O'Neil. The only previous sighting was on Oct. 8-11, 1969.

WOOD THRUSH: Saskatoon's first record of this species was observed in the city on May 24, 1973. Further details in the March, 1974, Blue Jay.

NORTHERN PARULA WARBLER: Two observed in the city by Frank Roy, Fred Waite and Martin Brilling on May 27, 1972, was the first record for Saskatoon.

BLACK-THROATED BLUE WARBLER: A female observed in the city on Sept. 19, 1972, by the writer was the first record. Males were seen in the city on 


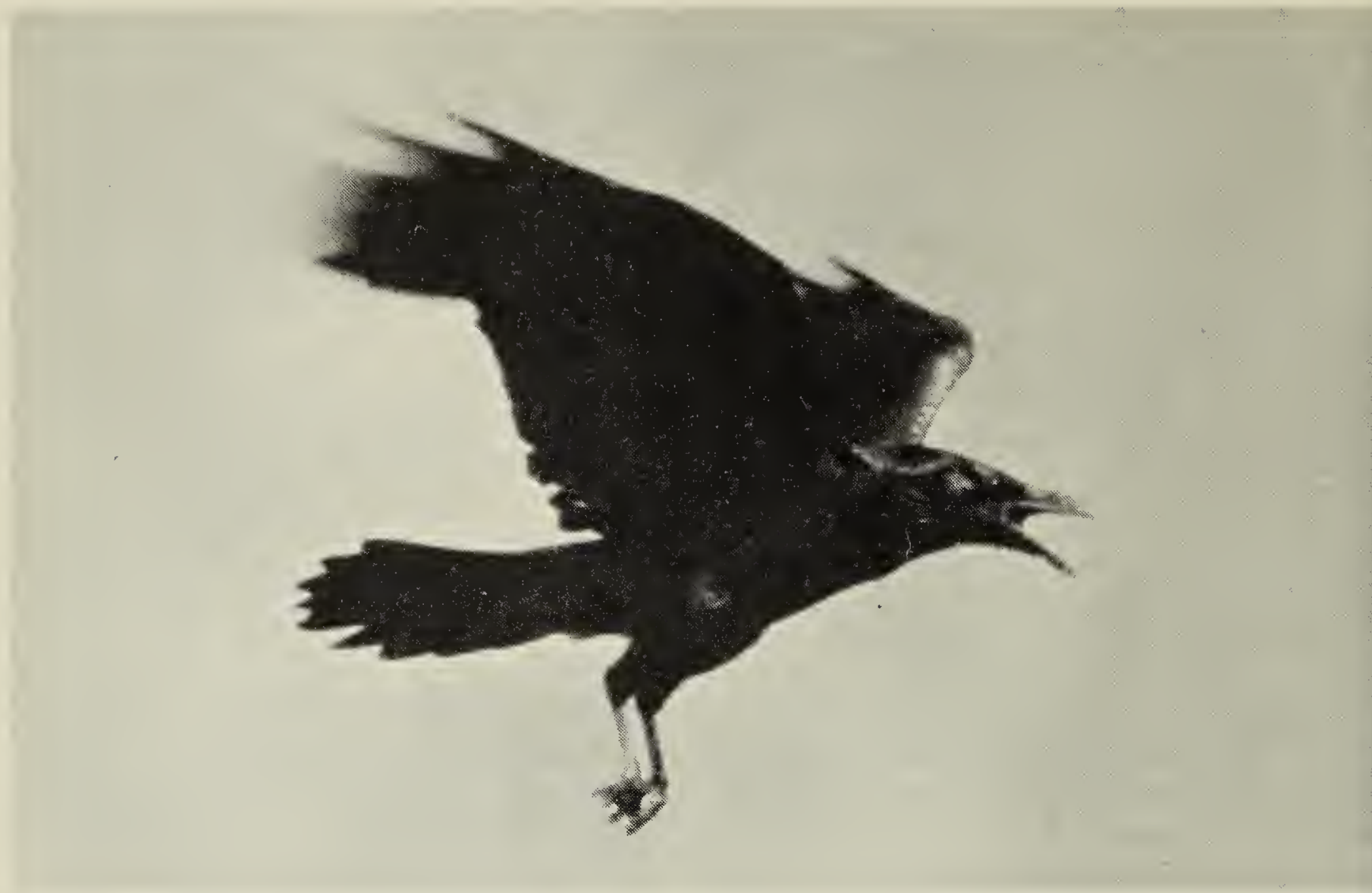

Oct. 12 and 13, 1972, by Lynn Oliphant and on Oct. 27, 1973, by Dr. and Mrs. Houston.

YELLOW-RUMPED WARBLER: A brood of three young being fed out of the nest near the city on July 10, 1973, was the first breeding record (Wayne Harris).

BLUE GROSBEAK: Saskatchewan's first sight record was a pair observed by Dr. and Mrs. Pepper on May 26, 1974, north of Pike Lake. The large white beak and two rusty wingbars separated the male from a bluebird. This species is not usually found north of the Black Hills in South Dakota.

DICKCISSEL: On July 4, 1973, two males and at least one female were identified by $\mathrm{Mr}$. and Mrs. J. A. Wedgwood in a forage crop south of the city. The only previous record was in July, 1966.

LAZULI BUNTING: On July 4, 1973, the first record of this species was observed by J. A. Wedgwood west of Dundurn.

COMMON REDPOLL: In June, 1970, a flock of five or six flying young was the second breeding record for the city.
They were observed in the city by Mrs. S. Aldous.

SMITH'S LONGSPUR: On May 10 , 1970, three birds were observed by J. A. Wedgwood near Tessier. Single birds were observed by Wayne Renaud and J. P. Secter northeast of the city on May 4, 1972, and again on May 13, 1972, by J. B. Gollop. On May 8, 1973, a flock of approximately 25 birds was observed near Meacham. just east of the district by the writer.

In addition to the above list the following observations during this period are worthy of brief mention Cinnamon Teal (4 birds/3 dates) Wood Duck (1/1), Whooping Crane (18/11), Parasitic Jaeger (1/1), Grea Crested Flycatcher (5/8), Gray Jay (4/4), Common Raven (55/19) Mockingbird (6/9 plus one pair which summered near Clavet), Eastern Bluebird ( $9 / 4$ plus one female which mated with a male Mountain Bluebirc and raised five young in 1974), Town send's Solitaire (1/1), Westeri Tanager (2/2, and Grasshoppe Sparrow $(1 / 1)$. 